\title{
The collusion detection in public procurements - selected methods applied for the road construction industry in Poland
}

\author{
Andrzej Foremny ${ }^{1}$, and Hubert Anysz ${ }^{1}{ }^{*}$ \\ ${ }^{1}$ Warsaw University of Technology, Faculty of Civil Engineering, Institute of Building Engineering, \\ Division of Production Engineering and Construction Management, Al. Armii Ludowej 16, 00-637 \\ Warsaw, Poland
}

\begin{abstract}
Based on successful international examples of collusion detection, four indicators of the collusion have been chosen and analysed in this paper. The research was done for the majority of tender procedures in the road construction industry, in Poland that was finished in 2016 with the selection of a general contractor. Based on $[1,2,3]$ the following four indicators were chosen: the number of offers placed in the tender procedure, the range of bid prices being offered, exactly the same set of offerors in a few tender procedures, repeating ordering the works execution to the same contractor in a given geographical region.
\end{abstract}

\section{Introduction}

The reason for introducing the system of public procurements was to provide a real market competition for the orders placed by the municipal or national offices, to ensure that public orders can achieve efficiency as high as the private ones [4]. The specific character of the construction industry (extremely high value of orders, very limited number of companies capable to handle the road construction contracts, specialization of contractors) creates favourable conditions for non-concurrent behaviours of the participants of the tender procedure $[1,5]$. Sometimes a forbidden practice of discussing bid prices between offerors before placing the offers takes place. These factors of non-market origin [6] influence the contractors' decisions about participation in a tender procedure. As a result, the client receive offers where all bid prices are over the market level. Next - even choosing the lowest one - the efficiency of spending public money decreases [5] and market is abused.

It is rather difficult to prove that collusion took place. As it is a forbidden practice, the police and other secret service forces have been involved to discover the matter of the secret agreements between offerors. It is easier - based on the information collected from the offers already placed in the past - to evaluate if collusion took place in a given tender procedure. The client, suspecting the collusion, can revoke the tender procedure not choosing any offer as the best one [4]. If collusion takes place and is detected before a contract execution, a client can save money, but it significantly delays the start of work

*Corresponding author: h.anysz@il.pw.edu.pl 
because the new invitation to tender has to be announced. It is crucial then, that the suspicion of collusion should be detected as soon as possible backed by a strong base. For the national economy and the future road users, significant delay of road construction can be near as much inefficient as building it on planned time paying the over-the-market price. It can be calculated based on [7].

\section{Input data description}

The authors of the paper prepared a database of tenders gathering information from web pages of institutions that were public ordering parties. The database consists of 98 public tenders for road construction or reconstruction whose results were published in 2016 in Poland, of a winning tender offer value 10 million PLN or more. Each record consists of the following data: organizer name, localization of construction works, road type (highway, expressway, national way, voivodship road, county road), type of works (construction, reconstruction), contract scope (design, design and build), list of all offerors not excluded, list of all price offers submitted.

\section{Criteria applied for the collusion detecting}

Numerous studies into bid collusion at auctions have been conducted in the past. The empirical literature is focused on the detecting of collusion using past examples. Porter and Zona [5], Zona [4] propose the tests for collusion detection in the context of highway construction data and school milk markets. In the case of the Ohio school milk case [5], the economic analysis has shown how prices were lower when (transportation) costs were higher which is inconsistent with competition but quite consistent with a particular collusive scheme [8].

The collusion agreements can be complicated to detect as they are typically negotiated secretly. In industries where collusion is common, however, suppliers and purchasers may be aware of longstanding bid-rigging conspiracies [9]. The authors based on official publications of the organization OECD and UOKiK selected and applied four methods of searching for collusion behaviour in this paper [3,9].

\section{The number of offers placed in a tender procedure}

A small number of offers in a particular tender in comparison to other similar tender procedures may signalize a higher possibility of collusion. The authors has taken into consideration only the offers that were accepted and published on an official tender results sheet. Thus the list does not show the offers that were not valid or that were withdrawn by the offerors before the results publication. The most frequent number of the offers placed was 5 (in 18 procedures). The minimal number of offerors was 3 , the maximal number of offerors was 20 , the average number of offerors was 7,8 . The average number of offerors in one tender calculated in this research is very similar to 8,2 that was calculated in the previous study in 2014 [1]. A histogram was created (see fig. 1). In the analyzed database there are 6 tenders with only 3 offers placed. It can be a sign of collusion in comparison to the average number of offers in a single tender which was 7,8 . 


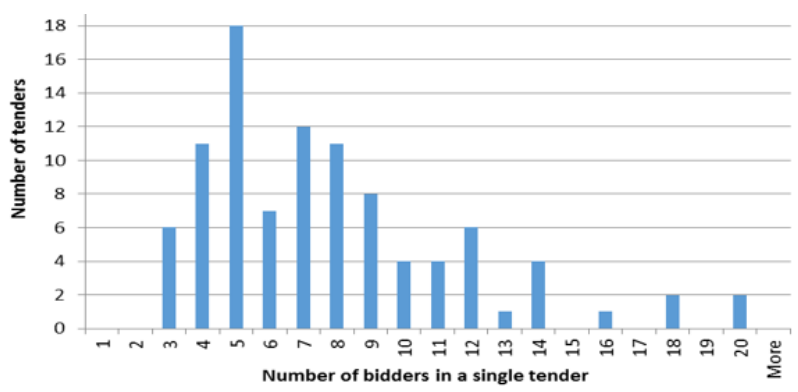

Fig. 1. Histogram of the number of tenders with the number of bidders given on the horizontal axis [own elaboration].

\section{The range of bid prices being offered}

The decision to bid and to calculate a bid price taken by a general contracting company depends on many factors: technical, economic, geographical and others $[6,10,11,12,13]$. There are many available methods of multicriteria assessment [14]. A small range of bid prices in comparison to other, similar tender procedures may signalize higher possibility of collusion. The range $R_{i}$, showing the percentage by which the lowest (winning) bid is lower than an average bid in a procedure $i$, was calculated using the formula:

$$
R_{i}=\frac{V_{a v i}-V_{\min i}}{V_{a v 1}} * 100 \%
$$

where:

$R_{i} \quad$ the range (defined above) for procedure $i$

$V_{\min i} \quad$ the lowest value of an offer in procedure $i$

$V_{a v i} \quad$ the mean average value of offers in procedure $i$

In the case of calculation in this chapter, 14 records from the database had to be eliminated because they missed bidding price data. The results are presented in fig. 2 .

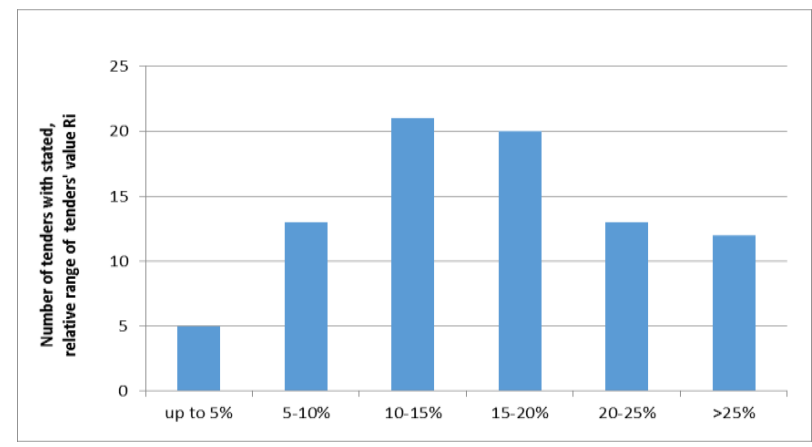

Fig. 2. Histogram of the number of tenders with the value of range $R_{i}$ within specified percentage intervals [own elaboration].

The average range $R$ for analyzed tenders was $16,9 \%$. There were 5 tenders that had an extremely narrow range and can be suspected of collusion behavior between offerors. The minimal range observed in a single tender was lower than $1 \%$, this was a very valuable tender - the winning offer showed the price higher than 400 million PLN. The ranges observed in this research are similar to the recorded in a previous study in 2014 [1]. 


\section{The geographical criterion of the collusion detection}

On an abused market a geographic allocation of winning tenders may occur. Within the analysed year 2016 a list of 98 tenders were checked. There were 756 offers placed by 138 companies or consortia. Collusion can be done between companies that repeatedly place offers and - from time to time - win. The tab. 1 shows how many procedures were won by a certain number of companies.

Table 1. Numbers of wins and number of companies [own elaboration].

\begin{tabular}{|c|c|c|c|c|}
\hline \multirow{2}{*}{} & \multicolumn{4}{|c|}{ Number of wins } \\
\cline { 2 - 5 } & 0 & 1 & 2 & 3 and more \\
\hline Number of companies that won given number of times & 99 & 27 & 9 & 3 \\
\hline
\end{tabular}

It was assumed that the company involved in a collusion has to win one or more bidding procedures. The more price bids are placed by a single company, the more orders are won thus higher probability of participation in a collusion. It is not a kind of a proof that collusion took place. It is rather excluding from the collusion by searching the areas where entities have not won any contract.

Table 2. Attempts and wins of the key players [own elaboration].

\begin{tabular}{|l|c|c|c|}
\hline & Company A & Company B & Company C \\
\hline The number of tenders attempted & 90 & 56 & 72 \\
\hline The number of tenders won & 17 & 23 & 13 \\
\hline
\end{tabular}

There are the three leading players in the road construction industry in Poland (taking into consideration analysed database of tenders in 2016). Each of these companies won 3 or more tender procedures for building or designing and building a road, where the contract values were higher than 10 million PLN. The data concerning their attempts are summarized in tab. 2 .

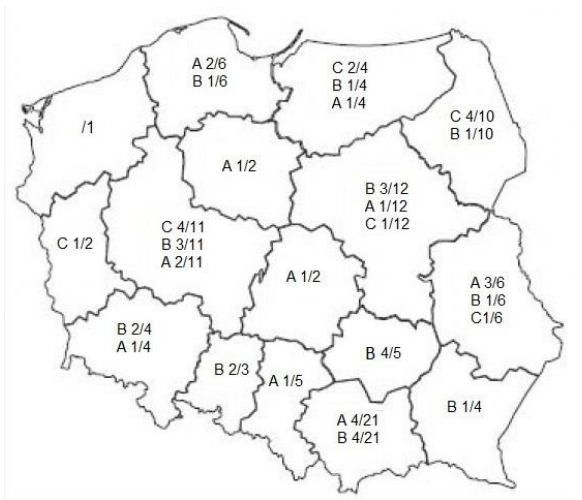

Fig. 3. The procedures won by $\mathrm{A}, \mathrm{B}$ or $\mathrm{C}$ in voivodships (the total number of procedures is shown after slash) [own elaboration], with the use the graphics from [15].

The leading three players have won 54\% (53 out of 98) tender procedures, signing the contracts for ca. 5.537 million PLN (out of ca. 11.803 million PLN). The fig. 3 shows voivodships where the companies $\mathrm{A}, \mathrm{B}$ and $\mathrm{C}$ have won the procedures.

Based on fig. 3 the following findings can be emphasised:

- the company A was the only one (from A, B, and C) that has won in 3 voivodships, 
- the company B was the only one (from A, B, and C) that has won in 3 voivodships,

- the company C hasn't won any tender procedure in Southern Poland,

- there are 6 voivodships where $\mathrm{A}, \mathrm{B}$ and $\mathrm{C}$ have won proportionally much more procedures than average; they are shown in tab. 4.

Table 4. Percentage of procedures won by A, B or C in selected voivodships [own elaboration].

\begin{tabular}{|c|c|}
\hline Voivodship by its capital & $\begin{array}{c}\text { Procedures won by A or B, or } \\
\text { C }\end{array}$ \\
\hline Olsztyn & $100 \%$ \\
\hline Lublin & $83 \%$ \\
\hline Poznań & $81 \%$ \\
\hline Kielce & $80 \%$ \\
\hline Wrocław & $75 \%$ \\
\hline
\end{tabular}

The irregularities found, based on the geographical criterion are essential, but part of them can arise from natural reasons. One of them is the lack of the company $\mathrm{C}$ among winners in Southern Poland. This company has won 13 tender procedures, but there are 17 voivodships in Poland (4 more that procedures won by C). Special attention should be paid to the tenders listed in the tab. 4. In these voivodships, only 5 out of 30 procedures were not won by the three key players $(83 \%$ of orders there has gone to A, B or C company, compared to $54 \%$ totally).

\section{The coincidence of participants and the winners as a criterion of collusion detection}

The same set of offerors in a few tender procedures may signalize higher possibility of collusion. One of the best tools for searching coincidences is an association analysis [16]. The collected and prepared data is searched in order to find the set of factors that is repeatedly accompanied by the examined phenomenon (the phenomenon appears repeatedly too). These factors are often called the bodies $(b)$, and the phenomenon is called the head $(h)$ [17]. Measurements of the frequency of appearing the rule $b \rightarrow h$ (if the body has appeared, then the head appears too) is executed by calculating two proportions called support (sup) and confidence (conf). They are defined as:

$$
\sup (b \rightarrow h)=\frac{n(b \cap h)}{N}
$$

and

$$
\operatorname{conf}(b \rightarrow h)=\frac{n(b \cap h)}{n(b)}
$$

where:

$n(b \cap h) \quad$ the number of cases when $b$ and $h$ appear simultaneously,

$N \quad$ the total number of examined cases,

$n(b) \quad$ the number of cases when $b$ appears (regardless the head).

The usefulness of association analysis is in the fact that the body can be represented by a coincidence of many factors accompanying the examined phenomenon [18]. Then:

$$
b=\left(b_{1} \cap b_{2} \cap b_{3} \cap \ldots \cap b_{m}\right)
$$


where:

$m$

the number of factors being checked every time together with the phenomenon appearance.

The head can be described as a simultaneous appearance of more than a single phenomenon (e.g. joint appearance of three sub-phenomena creating the examined phenomenon). For the analysis of tender procedures, the STATISTICA 12 computer program was used with its function association analysis. There were 7, following bodies:

- the order scope ( 0 for ordering building works; 1 for the order "design and build");

- the type of a road ( $\mathrm{H}$ for highways, $\mathrm{E}$ for express roads, $\mathrm{K}$ for national roads, $\mathrm{W}$ for voivodship roads, $P$ for county roads);

- placing an offer by the company A (1 for an offer placed, 0 for not placing an offer);

- placing an offer by the company B (1 for an offer placed, 0 for not placing an offer);

- placing an offer by the company C (1 for an offer placed, 0 for not placing an offer);

- number of participants in a tender procedure ( 0 for 5 or less, 1 for more than 5$)$;

- value of an order meant as the lowest (winning) bid price ( 0 for the contracts with value lower than 100 million PLN, 1 for the contracts of higher value);

The head was defined as:

$$
h=\left(h_{A} \cup h_{B} \cup h_{C}\right)
$$

so the value of the head could be

$$
h= \begin{cases}1 & \text { when the winner was } A \text { or } B \text { or } C \\ 0 & \text { when the winner was other }\end{cases}
$$

In a total number of 98 analyzed procedures, there were only 4 where no offer has been placed, by any company from the three leading players. The thresholds for the value of a contract and a number of participants in a tender procedure had to be set manually. The software - after setting the minimum values separately for the confidence and for the support - search for all association rules fulfilling the limits of conf and sup [19]. As a collusion happen very rarely (due to the authors' belief) the support was set to $5 \%$. The lowest limit of confidence was set to $50 \%$. The number of the rules found was 39 . The results with the highest confidence are shown in tab. 5.

Table 5. The rules found with the highest confidence [own elaboration].

\begin{tabular}{|c|c|c|c|c|c|}
\hline Label & If body & than & Head & sup & Conf \\
\hline R1 & WAY $=\mathrm{W}, \mathrm{B}=1, \mathrm{VALUE}=0$ & $==$ & 1 & 21,4 & 75,0 \\
\hline $\mathrm{R} 2$ & $\mathrm{WAY}=\mathrm{W}, \mathrm{A}=1, \mathrm{~B}=1, \mathrm{C}=1$ & $==>$ & 1 & 20,4 & 76,9 \\
\hline $\mathrm{R} 3$ & $\mathrm{WAY}=\mathrm{W}, \mathrm{B}=1, \mathrm{C}=1$ & $==>$ & 1 & 21,4 & 77,8 \\
\hline $\mathrm{R} 4$ & $\mathrm{WAY}=\mathrm{W}, \mathrm{C}=1, \mathrm{~B}=1, \mathrm{VALUE}=0$ & $==>$ & 1 & 17,3 & 81,0 \\
\hline $\mathrm{R} 5$ & $\mathrm{WAY}=\mathrm{W}, \mathrm{A}=1, \mathrm{~B}=1, \mathrm{C}=1, \mathrm{VALUE}=0$ & $==>$ & 1 & 17,3 & 81,0 \\
\hline
\end{tabular}

Within all 34 rules found, if the type of the road was mentioned, it was always a voivodship road. The most interesting rules are R2 and R5. If all leading players (the companies labelled as A, B, C) have placed an offer in a given tender, then the probability of winning the contract was $76,9 \%$ (for the analyzed database from the year 2016). If the condition about the contract value was considered (VALUE $=0$ when the contract value is below 100 million PLN), the confidence increases to $81 \%$ (rule R5). 


\section{Conclusions}

In the cases of collusion suspected the bidding procedures were listed separately for each criterion in tab. 6 .

Table 6. The numbers of bidding procedures fulfilling each criterion of the collusion detection [own elaboration].

\begin{tabular}{|l|c|c|c|c|}
\hline & $\begin{array}{c}\text { The low number } \\
\text { of bids } \\
\text { (criterion No. 1) }\end{array}$ & $\begin{array}{c}\text { The small range } \\
\text { of the price bids } \\
\text { (criterion No. 2) }\end{array}$ & $\begin{array}{c}\text { The geographical } \\
\text { criterion } \\
\text { (criterion No. 3) }\end{array}$ & $\begin{array}{c}\text { Repeating joint } \\
\text { participation } \\
\text { (criterion No. 4) }\end{array}$ \\
\hline $\begin{array}{l}\text { Numbers of } \\
\text { procedures } \\
\text { fulfilling the } \\
\text { criteria }\end{array}$ & 6 & 5 & 25 & 20 \\
\hline
\end{tabular}

The thresholds in each criterion were set by the authors, so they are subjective and relative. The thresholds of criteria 1 and 2 were based on $[1,3,9]$. Next, the number of the suspected procedures is extended. It was assumed that the more criteria is fulfilled by a certain procedure, the higher is the probability of a collusion appearance. The result of the check is shown in tab. 7.

Table 7. The numbers of bidding procedures fulfilling the criteria of the collusion detection [own elaboration].

\begin{tabular}{|l|c|c|c|c|}
\hline & 1 criterion & 2 criteria & 3 criteria & 4 criteria \\
\hline Procedures fulfilling the criteria & 28 & 12 & 0 & 1 \\
\hline
\end{tabular}

It is necessary to emphasize, that the collusion is found if there is a court confirming sentence. Otherwise - like in this paper - only the risk of appearing of a collusion can be discussed. For the time being, there is no confirmation of any collusion in the analyzed tenders. Thus, there is no possibility to discuss more, how many criteria should be fulfilled to predict a high risk of collusion as high. It can be stated that the procedure fulfilling the four criteria (formulated by the international organization, and some national institutions set up to protect the market from non-concurrent behaviors) is much more suspected for a collusion, than the procedure that fulfill only one.

If it is confirmed, that fulfilling only the one criterion of a collusion is a strong indicator of a fraud, it will mean that in $42 \%$ procedures for the road construction in Poland in 2016 (41 out of 98 analyzed) achieved price was not-concurrent. If 3 or 4 criteria are required, the road construction market will look much better. Only one procedure would be suspected as non-concurrent. Stating the collusion requires a huge effort, and it is a time-consuming process. It is much easier to extend requirements of the scope of information provided by offerors in their tender documents [20]. A higher level of details would allow the clients for easier inconsistencies finding in price bids and for easier excluding inconsistent, overpriced bids. The current scope of offers, as well as ordering construction works together with a design does not allow for successful, quick exclusion of inconsistent, overpriced bids from tender procedures.

\section{References}

1. H. Anysz, A. Foremny, J. Kulejewski, Estimating potential losses of the client in public procurement in case of collusion utilizing a MLP neural networks, Technical Transactions 111/1-B, 105-118, DOI: 10.13140/2.1.2409.6321 (2014) 
2. Y.C.A. Capobianco, Ex Officio Cartel Investigations And The Use Of Screens to Detect Cartels, OECD (2013).

3. Urząd Ochrony Konkurencji i Konsumentów, Zmowy przetargowe" (2017)

4. J.D. Zona, Bid-rigging and the Competitive Bidding Process: Theory and Evidence, Ph.D. Dissertation, State University (1986)

5. R.H. Porter, J.D. Zona, Detection of Bid Rigging in Procurement Auctions, Journal of Political Economy 101/ 3, 518-538 (1993)

6. A. Leśniak, Classification of the Bid/No Bid Criteria - Factor Analysis, Archives of Civil Engineering 61/4, 79-88, DOI: 10.1515/ace-2015-0037 (2015)

7. Instytut Badawczy Dróg i Mostów, Instrukcja oceny efektywności ekonomicznej przedsięwzięć drogowych i mostowych dla dróg wojewódzkich, (2008)

8. J. Harrington, Behavioral screening and the detection of cartels, European Competition Law Annual (2006)

9. OECD, OECD recommendation of the council on fighting bid rigging in public procurement (2012)

10. A.S. Bageis, C. Fortune, Factors affecting the bid/no bid decision in the Saudi Arabian construction contractors, Construction Management and Economics 27/1, 53-71 (2009)

11. M.S. El-Mashaleh, Decision to bid or not to bid: a data envelopment analysis approach, Canadian Journal of Civil Engineering (2010)

12. A. Enshassi, S. Mohamed, A. El Karriri, Factors affecting the bid/no bid decision in the Palestinian construction industry, Journal of Financial Management of Property and Construction 15/2, 118-142 (2010)

13. A. Leśniak, E. Plebankiewicz, Modeling the Decision-Making Process Concerning Participation in Construction Bidding, Journal of Management in Engineering 31/2, 4014032, DOI: 10.1061/(ASCE)ME.1943-5479.0000237 (2015)

14. S. Biruk, P. Jaśkowski, A. Czarnigowska, Modeling Contractor's Bidding Decisions, Procedia Engineering 182, 91-98, DOI: 10.1016/j.proeng.2017.03.125 (2017)

15. Centrum edukacji i nauczania, [Online:] http://www.nowowydane.pl/cen [Access: 15Jan-2018]

16. D.T. Larose, C.D. Larose, Discovering Knowledge in Data, Willey IEEE, ISBN97881-265-5834-6 (2016)

17. T. Morzy, Eksploracja danych. Metody i algorytmy, PWN (2013)

18. M. Pęczkowski, M. Lasek, Analiza asocjacji i reguly asocjacyjne w badaniu wyborów zajęć dydaktycznych dokonywanych przez studentów. Zastosowanie algorytmu Apriori, Ekonomia. Rynek. Gospodarka. Społeczeństwo (2013)

19. Internetowy podręcznik statystyki, [Online:] https://www.statsoft.pl/textbook/stathome.html. [Access: 10-Jan-2018]

20. H. Anysz, Założenia systemu rozliczeń TKW $+M$ (techniczny koszt wytworzenia plus marża), Przegląd Budowlany 1 (2018) 